\title{
The Cardrona Hotel: Creating a New Zealand heritage icon
}

\section{ABSTRACT}

1.
On the road between the famed tourist hubs of Wanaka and Arrowtown on New Zealand's South Island lies the former 1860s gold-rush-era town of Cardrona. There, beside an immaculately kept heritage precinct of nineteenth-century wooden buildings, tourists pause at the Cardrona Hotel, an architectural relic of the rush for gold in Central Otago. This hotel has emerged in guidebooks and local histories, and on social media sites and ratings guides, as a tourism and craft beer 'must-do' and, according to Heritage New Zealand, has become New Zealand's most photographed hotel. Its popularity defies belief and even logic, and yet each new visitor to the region appears determined to leave with at least one photograph of its distinctive facade in their portfolio. The story behind the survival of the heritage-listed structure and its elevation to the heights of popular and tourist culture 'icon' status stems from a combination of its remote location, the enduring romanticization of the gold rush, a succession of eccentric owners, the mythopoeia of a popular book from the 1950s and its inclusion in a brewer's marketing campaign. Each has scaffolded the Cardrona Hotel to become iconic to the gold-rush era, heritage tourism and New Zealand's popular culture and identity.

\section{INTRODUCTION}

On the spectacular Crown Range Road between the Central Otago tourist boom towns of Wanaka and Arrowtown on the South Island of New Zealand lies the old gold-rush town of Cardrona. There, among new schist

\section{KEYWORDS}

false-front architecture gold rush

Otago

heritage

hotel

mythopoeia

tourism 
stone-fronted townhouses and beside an immaculately kept heritage precinct of nineteenth-century wooden school buildings and church, travellers pause at the Cardrona Hotel, an architectural relic of the Central Otago gold rush. The Cardrona has emerged on social media sites and ratings guides, and in various guidebooks and local histories, as a tourism and craft beer 'heritage must-do' and, according to Heritage New Zealand, has become New Zealand's most photographed hotel (Bauchop 2011). The Crown Range Road is now a busy tourist thoroughfare but, as recently as the 1990s, was little more than a narrow, poorly maintained gravel route considered so hazardous that rental car companies refused insurance cover to anyone tackling its curves. The tourists who pause at the Cardrona hotel today encounter a building that has entered local, national and international folklore as a quintessential example of false-front gold-rush architecture and has also emerged in the collective New Zealand imagination as a unique heritage and popular culture icon.

As an 'iconic' hotel, the Cardrona Hotel does not own an exclusive title; each state in Australia has hotels that are labelled icons for a variety of reasons. These can include their inclusion in movies, such as the Palace Hotel in Broken Hill, New South Wales, from Priscilla, Queen of the Desert (1994) or Mick Dundee's pub in Crocodile Dundee (1986), McKinlay's Walkabout Creek Hotel in Queensland. Other hotels are icons due to their notoriety in historic events, such as Tanswell's Commercial Hotel in Beechworth, Victoria, which played host to the Kelly Gang bushrangers in the 1870s. Some are celebrated in popular songs, such as Lees Hotel Motel in Ingham, Queensland, which was Slim Dusty's 'Pub with No Beer' in the 1959 hit (Halabi and Williams 2010). Yet others make the lists for their association with major gold rushes,

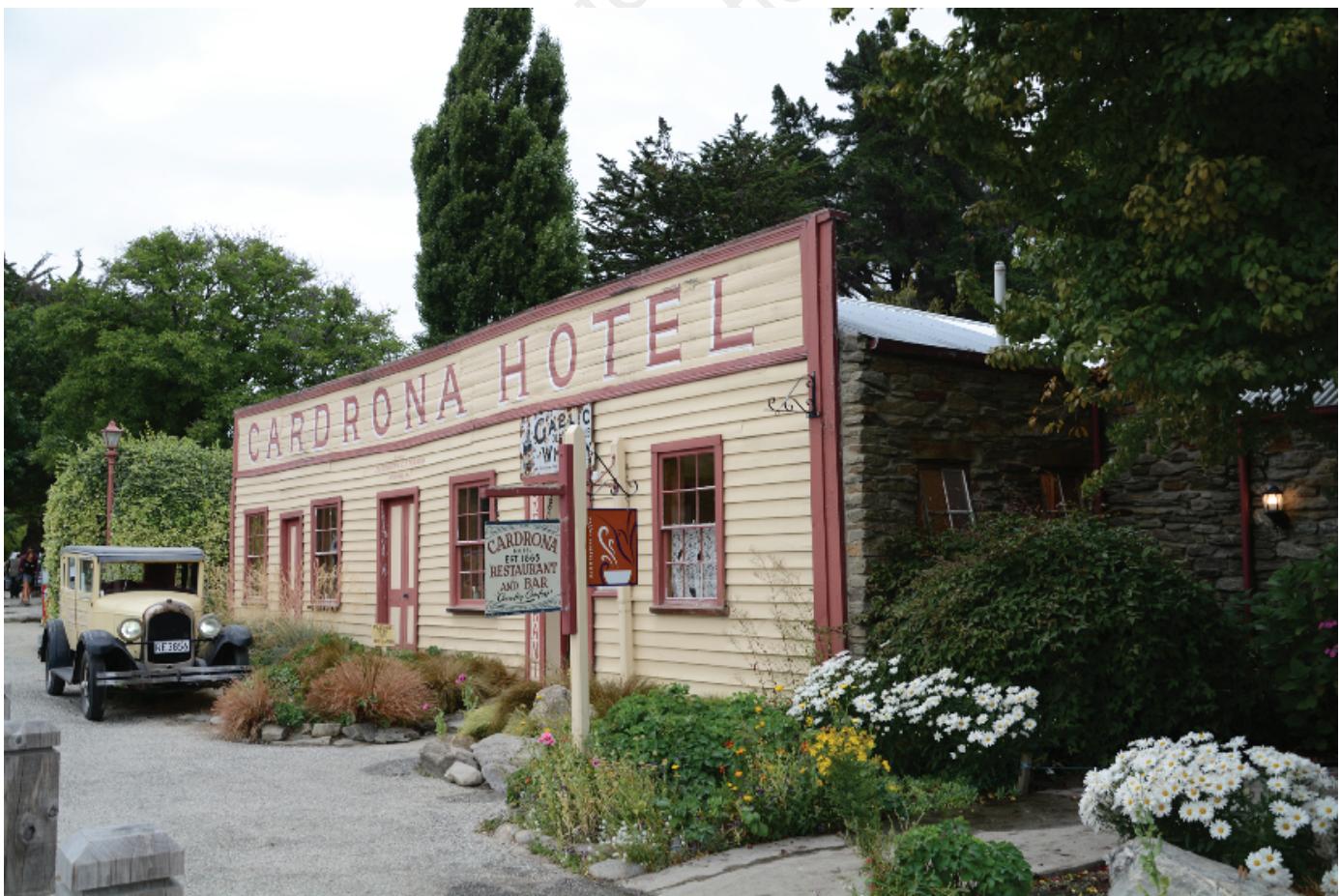

Figure 1: Photograph by author, Cardrona Hotel. @ Lloyd Carpenter 2018.
1. 2. 3. 4. 5. 6. 7. 8. 9. 10.

11.

12.

13.

14.

15.

16.

17.

18.

19.

20.

21.

22.

23.

24.

25.

26.

27.

28.

29.

30.

31.

32.

33.

34.

35.

36.

37.

38.

39.

40.

41.

42.

43.

44.

45.

46.

47.

48.

49.

50.

51.

52. 
1. such as Bendigo's Shamrock Hotel and the Gold Mines Hotel (both Victoria), Kalgoorlie's Exchange Hotel (in Western Australia) or The Imperial in Ravenswood (Queensland).

Notwithstanding each hotel's importance as heritage architectural treasures or historic artefacts or for their usage in popular culture, none of these 'icons' combines these aspects in one structure as does the Cardrona. This was not, however, the reason for the Cardrona Hotel's continued survival or its existence - which is a mixture of historical accident and its proximity to a natural bridge over a dangerous river, a location that shaped transport patterns, and its use (or neglect) for hundreds of years.

\section{ORAU: CARDRONA'S MĀORI PATHWAYS}

The Cardrona Valley was known by Māori as 'Orau'. The safe river crossing over the Kawarau River made it the main route for Southland Māori travelling to and from the pounamu (nephrite jade) source at the Arahura River on West Coast. The route north from Murihiku (Southland) to Arahura runs up the Nokomai Valley and into Te Papapuni (Nevis Valley), at the end of which a natural rock bridge called Whatatorere (literally 'flying ladder') crossed the Kawarau River. On official New Zealand topographical maps, this landscape feature is marked as 'Chalmer's Leap'. From the bridge, the route traverses the Crown Saddle and the Cardrona Valley, sidles Lake Wanaka, crosses Tioripatea (Haast Pass) and continues on up to Arahura (Holmes cited in Stephenson et al. 2004: 27).

The stone bridge of Whatatorere would prove equally important to the first European explorers in the 1850s (McClymont 1940: 125; Temple 1985: 95-99). Each used Māori guides to keep them out of trouble and to identify the greenstone routes using the bridge (Tuckett 1844; Barnicoat n.d.). When the Scottish-born Provincial Government Surveyor John Turnbull Thomson came through the area, he renamed Orau after Cardrona House in Scotland (Hall-Jones 2005: 95). The early pastoralists William Rees and Nicholas von Tunzelmann moved the first herds of sheep to Wakatipu via the bridge in 1860 (Duncan 1888: 13), and it similarly proved useful to gold miners seeking a safe route to Central Otago's Lakes District goldfield in the period from 1862 to 1888 (Carpenter 2011: 34; McClymont 1940: 124-30; Middleton 2006: 4). But ultimately, it was gold that created the township at, and named, Cardrona.

\section{RUSH FOR CARDRONA GOLD}

The Central Otago gold rush erupted in August 1862, when Californian veterans Horatio Hartley and Christopher Reilly deposited 1000 ounces of gold in Dunedin, collected a $£ 2000$ reward from the Provincial Council and announced the location of their find as in the Clutha River, near modern Cromwell (Anon. 1862a: 5, 1862b: 5). Miners rushed from Australia, California and Britain, and Eastern Otago's Gabriel's Gully, to the new gold country and, as they explored new valleys and regions, additional goldfields were found, registered and celebrated.

Cardrona gold was discovered in November 1862 by Australian veteran miners Michael Grogan, Patrick May and James Mullins, on their way to the newly declared Fox's Rush at the Arrow River (Grogan 1862: 3; Anon. 1862c: 4). The miners' route traversed the Cardrona, where the stone bridge provided a safe crossing point and avoided a dangerous, precipitous stretch of the Kawarau Gorge. Grogan and his mates found loose gold in Cardrona riverbank loam, which prompted a rush of about 1000 miners there (Keddell 1862a: 3). Goldfields' Warden Jackson Keddell was initially not impressed, 
reporting that the Cardrona has not realized the sanguine expectations of its prospectors, and is reported as being very patchy' (Keddell 1862b: 6; Anon. 1862d: 5), but then changed his mind, observing that accounts are 'of a very encouraging character [...] prospectors on the Cardrona are stated to be "nuggetting" it out' (Anon. 1862e: 7). However, 'patchy' gold became the byword for the Cardrona field and richer, more consistent, fields drew miners away and, within a few months, the population halved (Pyke 1862: 6).

The Cardrona Valley and its safe crossing over the Kawarau river continued to be an important route to the Arrow and Shotover goldfields (Anon. 1863: 6), and the traffic and local demand was enough to maintain a business hub of hotels, stores and banks in Cardrona, and a commercial stable. But the population and businesses dwindled as gold returns fell, a diminution that reversed dramatically in December 1865 when Otago's first 'deep lead' river terrace claims were found in Cardrona. Warden Lowther Broad announced that a 150 feet wide, mile-long lead had been found at a depth of 40 feet and that several claims were doing well, including one two-man operation that deposited 1270 ounces of gold in four months (Broad 1865; Anon. 1865a: 4). Miners and merchants returned to Cardrona, forming mining syndicates and opening new businesses. James Lawrence opened a twin to his Cromwell Bakery; John Hetherington, Cromwell's pioneer storekeeper, erected a store and worked with former Otago Mounted Constable James Quain to 'paddock' mine a claim (Anon. 1868a: 5); Josiah Mitchinson, a veteran of deep lead mining at Ballarat, moved from the Arrow to Cardrona to form a syndicate and open a store (Mitchinson et al. 1864; Anon. 1869a: 2); and Charles and William Colclough expanded their retail operation.

Through this process, the town evolved into two settlements, known as the Upper and Lower Townships. The Lower Township was where most of the miners had their cottages and was where, in 1863 and 1864, and then again from 1873, Mr and Mrs Giacchimo Lafranchi established and ran the All Nations Hotel. The Upper Township was the main business area and is where the modern town and the Cardrona Hotel are located. When Cardrona's deep lead rush erupted, this was the place where George and Rebecca Bond headed.

\section{GEORGE AND REBECCA BOND}

After George Butler Bond's general store failed in Melbourne, he filed for bankruptcy in 1859 (Anon. 1859: 6). During his discharge period, he worked as shopman for Alston and Brown, linen-drapers in Melbourne (Anon. 1860: 6), but when news of the 1862 Central Otago rush broke, he left Victoria with his wife Rebecca, heading for Central Otago. They initially settled at Arthur's Point near Queenstown, where they purchased the Bridge End Hotel and, in partnership with Queenstown Hotelier John Dohey (Anon. 1865a: 1), erected and ran a toll bridge, the first across the Shotover River (Anon. 1866b: 3, 1866a: 2). George formed the Shotover Gorge Association to coordinate syndicated mining ventures (Anon. 1864: 3) and established a new ferry on the Shotover at Big Beach (Anon. 1867: 3). Rebecca was busy too; adding to the son born in Melbourne a year after their 1861 marriage, the Bonds welcomed a daughter in 1864, another in 1865 and would have twins in 1869.

When news of Cardrona's deep lead riches broke at the end of 1865, the Bonds were among the many who considered moving. In 1866, George survived a bitter dispute with shareholders of his Syndicate (Anon. 1866c: 2, 1866d: 3), and by the end of 1867, sold the hotel, toll bridge and mining shares
1. 2. 3. 4. 5. 6. 7. 8. 9. 10. 11. 12. 13. 14. 15. 16. 17. 18. 19. 20. 21. 22. 23. 24. 25. 26. 27. 28. 29. 30. 31. 32. 
1.

2.

3.

4.

5.

6.

7.

8.

9.

10.

11.

12.

13.

14.

15. to move his family to Cardrona. With four partners, he secured a claim on a bend in the old riverbed and, by late 1868, his Empire Syndicate had found a rich seam at a depth of 130 feet, proof, according to the Otago Witness, 'of the indomitable perseverance of Mr Bond' (Anon. 1869b: 17). For seven years, the Empire Syndicate erected pumping gear, built tailraces and mined for gold, while two Chinese syndicates worked the ground adjacent to, and below, them in apparent harmony with their neighbours (Anon. 1875a: 3).

In addition to mining, in 1867 the Bonds built and opened the Empire Hotel, advertising that their 'newly-erected establishment is acknowledged to be one of the best and most comfortable family hotels in the district' and declaring that in addition to offering 'a first-class table', every attention would be paid to visitors and 'good attendance to horses' was also assured (Anon. 1868b: 3). The Empire Hotel was Cardrona's largest hotel, and rapidly became renowned for hosting dances, political speeches (Anon. 1869b: 17, 1875b: 6) and official meetings, with travellers visiting from Wanaka in the north, and Arrowtown and Queenstown to the South, to attend. The Bond's adjacent farm, garden and orchard were also famous, with plums, cherries, apples and pears featuring on their table d'hote (Anon. 1875a: 3).

Built as a solid, false-front structure of Baltic pine with a smaller, woodframed, corrugated iron-clad building behind it, the Empire Hotel was similar to other commercial buildings across the region, such as the Vulcan Hotel at St Bathans and Arrowtown's New Orleans Hotel. It was the architectural twin of another Central Otago gold-rush hotel, the Macetown Hotel, built by $\mathrm{Mr}$ and Mrs Giacchimo Lafranchi at around the same time (Anon. 1871: 2, 1872: 2). Details of the draughtsmen, and even the builders of these and other gold-rush-era structures, were not recorded, but given the similarity of some buildings, it is clear that there was a common architect, or at least a common contractor, involved in erecting several of them. These hotels were a far cry from the earliest days of the gold rush, when hotels and stores were little more than lengths of canvas stretched over wooden frames with a hopeful sign hung over the door: ephemeral buildings hastily erected and, then, quickly struck for transportation to a new goldfield when one erupted. Throughout Australasia, architecture and goldfields towns evolved as larger scale sluicing operations, quartz mines and even dredging companies developed ( $\mathrm{O}^{\prime}$ Mahony and Clark 2012: 173). In the latter half of the 1860s, the prevalence of regular wages and longer-term mining employment prospects saw the demand for, and construction of, more substantial hotels like the Empire, and the emergence of permanent gold towns such as Clyde, Cromwell, Arrowtown and Cardrona.

The process of mining ancient alluvial deposits buried under thick nonauriferous strata, known as 'deep lead mining' (Ritchie and Hooker 1997: 4), is dangerous, fickle and expensive and, if the golden 'lead' is lost, can be ruinous to recover. Worse, the shafts and tunnels used to mine it are susceptible to the encroachment of water. In October 1875, both circumstances devastated the Empire syndicate (Anon. 1875b: 6), leading one journalist to comment that 'Mr Bond speculated largely at the Cardrona; but latterly things have not been altogether satisfactory' (Anon. 1876a: 3) and another to remark on how badly he was taking the loss: he 'was well known throughout this and the neighbouring district [...] but latterly he appears to have given way to inebriation' (Anon. 1876b: 3). The mining losses - and probably his drinking - prompted the sale of his Empire Syndicate mining shares and the attempted sale of his and Rebecca's hotel in January 1876. The mining interests were sold to the Danish miner, explorer and entrepreneur George Magnus Hassing (Anon. 
1929: 4), but despite extensive promotion, there were no buyers for the hotel, despite it being declared to be a 'lucrative business in a prosperous district' (Anon. 1876c: 1).

The agent's advertisement shows the work that the Bonds had put into the Empire as it was

one of the best Hotel properties in the Province, consisting of hotel, containing 10 rooms, commodious stabling, bath-house and pump, four-acre paddock, well-fenced and under crop, a fruit garden and hotel furniture of a superior description, including an excellent harmonium and billiard table and a large and carefully selected stock of ales, wines and spirits.

(Anon. 1876b: 1)

Furthermore, on the land to be sold with the hotel was'an orchard, a few dairy cattle, horses, about three tons of potatoes and a water-powered chaff-cutter' (Anon. 1876b: 1). The insurance value was $£ 500$ and the business was, the agent urged, within the reach of 'persons of moderate capital' (Anon. 1876b: 1).

The Bonds' luck went from poor to tragic in February 1876, when George admitted himself into the Cromwell Hospital, suffering the effects of his heavy drinking and possibly suffering from depression. He left three days later without the consent of the surgeon, to stay at Goodger's Junction Commercial Hotel, where he was 'about town and conversed rationally enough with several residents [...] [and appeared to be in] improving health and spirits' (Anon. 1876b: 2). But at midnight the next day, Bond rose from his bed, donned his boots and coat, climbed out of his hotel window, stumbled down the river bank and drowned in the Clutha (Anon. 1876b: 2). The Cromwell Argus, Lake Wakatip Times and the Dunstan Times each editorialized his death, with the Clyde paper hinting that the death could be suicide, commenting that the pressure of a business downturn and the mining reversal 'preyed heavily on his mind, inducing him to do the rash act, which resulted in a watery grave' (Anon. 1876a: 3). Rebecca Bond leapt to her husband's defence, vociferously protesting the 'newspaper writer's endeavour to defame the memory [...] without a particle of direct evidence' (R. Bond 1876: 3), but this did not change the inquest's verdict that her husband was 'found drowned', having earlier 'jumped out of his bedroom window, and it was supposed, made for the Kawarau river' (Anon. 1876e: 4). Rebecca and her six children were left an estate of just $£ 172$ (G. B. Bond 1876).

Rebecca Bond did not remain in Cardrona. Instead, she purchased the Ballarat Hotel in Arrowtown. Advertising the Empire for rental and sale, she engaged local miner Henry Miller as manager, a role that he performed from 1876 to 1878 (Anon. 1878: 3). Adding to her woes, in 1878 nearly all mining activity ceased in Cardrona, when huge October flash floods wrecked headraces, pumps and water wheels, filling shafts, tailraces and underground workings with tailings. One press report noted that 'Cardrona suffered damage to such an extent that it will be almost extinguished as a mining centre. Many of the large claims are irreparably damaged' (Anon. 1878b: 16). Miners left for Macetown, Skippers Canyon and Bendigo (in Otago), where quartz mining offered consistent employment.

In 1879 the Empire's license lapsed, its doors were locked and the building stood empty (Anon. 1880a: 4). Clyde firm Preston and Cope attempted to sell it but despite it being the only hotel in the upper township, the post-flood mining environment appeared to extinguish any purchaser's interest (Anon. 1880b: 2). In 1885, Rebecca was again on the move, selling the Ballarat Hotel

1. 2. 3. 4. 5. 6. 7. 8. 9. 10. 11. 12. 13. 14. 15. 16. 17. 18. 19. 20. 
1. to purchase the newly refurbished Mountaineer Hotel in Queenstown (Anon. 2. 1885a: 2, 1885b, 1885c: 6) but, meanwhile, her Cardrona property continued 3. to sit neglected.

4.

5.

6.

\section{CARDRONA REVIVED}

In 1883, Cardrona miners formed a Mining Association, and wrote to the Lakes County Council for financial support, declaring their intent to prospect new ground, shift flood detritus and engage in systematic pit testing (Anon. 1883a: 8). Their application for support was accepted and community pressure for a road to be built linking Wanaka and Cardrona with Arrowtown and Queenstown also succeeded (Anon. 1883b: 12). The Mining Association's activities, together with small hydraulic claims run by the Try Again Company and the Lafranchis, were enough to sustain a stable, albeit small, Cardrona population, a thriving school run by former miner George Magnus Hassing (Anon. 1929: 4), the upper town store of Robert McDougall and Son, and the Lafranchi's All Nations hotel through the 1880s. However, the Empire and other hotels, stores and banks built in the 1860s sat empty, with one visitor in 1883 describing 'vacated hotels, a closed bank, and other premises now being ravaged by the ruthless hand of decay' (Perapatetic 1883: 10). Another, writing a year later, found 'the departed glory of this once-flourishing mining centre is now dismally demonstrated by the wreck of deserted public-houses, stores, and other buildings, now inhabited by rats, and presenting a most melancholy sight of decay' (Anon. 1884: 2). In contrast, both described a lower township of neat, well-kept cottages, each surrounded by extensive gardens.

Road-building from Arrowtown filled local newspaper columns throughout 1884 and in November of that year, the thoroughfare opened for traffic. In 1887, the All Nations hotel was sold to a Mrs Knowles so that the Lafranchis could focus on their mining interests. It continued to operate on a limited 'bush' license while nearly all the upper township's businesses remained abandoned. This changed in 1888, when a new rush broke out behind the lower township with 40, one-acre claims taken out on a newly discovered deep lead mine (Anon. 1888a: 2). The Lake Wakatip Mail announced that'the Cardrona is getting again a very important mining centre. Gold has been found in payable quantities over a large range of country, and every day applications are lodged' (Anon. 1888a: 2). The population grew, Mrs Knowles expanded accommodation at her All Nations premises and Robert McDougall announced that he would not only re-start his bakery but also open a butchery (Anon. 1890a: 2, 1888b: 2). This gold boom continued into the 1890s (Anon. 1892: 2).

Finally, Rebecca Bond received some long-awaited good news: the new, payable gold claims meant that 'business on the Cardrona has naturally taken a fresh start and all is activity and bustle, where, but a short time ago, affairs were as dull as ditchwater. The old [Empire] hotel formerly occupied by Mrs Bond is shortly to be re-opened' (Anon. 1889a: 2; Norman 1890: 31). Eleven years after Rebecca Bond abandoned the Empire Hotel to rats and decay, John Willoughby applied for the license and announced that he would extensively renovate the premises (Anon. 1889b: 2).

\section{JOHN AND ISABELLA WILLOUGHBY, JAMES PATERSON AND AFTER}

John Willoughby, a blacksmith, miner and farmer, was born in Cornwall in 1841 and from the age of 20 worked as a blacksmith on the goldfields of Victoria. Ten years later, he shifted to Cardrona and married Isabella Lafranchi, daughter of the All Nations Hotel proprietors (Anon. 1885d: 2). After purchasing, 
renovating and expanding the Empire in 1889, he changed its name to the Cardrona Hotel. A combination of the revival of mining and the completion of the road to the Central Lakes area meant that the Willoughby's newly refurbished, newly named Cardrona Hotel, began doing a good trade, offering rooms that were 'tidy and clean' with a 'good table' (Anon. 1890b: 5). The Willoughbys also ran a store, worked with the mining association and, in 1896, bought the All Nations Hotel but, just before deeds were exchanged, this burnt down (Anon. 1921: 5, 1896a: 5, 1894: 2, 1895: 22, 1896b: 2). In 1922, John died and Isabella Willoughby took over, running it until 1926, when she sold it to James Dunlop Paterson (Anon. 1922: 5). Paterson announced his intention to make improvements to the building and to cater to 'both tourist traffic and local trade' (Anon. 1926: 4).

Born in Oamaru, James Paterson grew up in Arrowtown and Cardrona, and earned renown as a bowler for the local cricket team (Anon. 1896c: 7). The nephew of Queenstown and Cardrona storekeeper Robert McDougall, Paterson served in the Otago Section in the Boer War (Anon. 1900: 28). When he returned from South Africa in 1901, he married Etty Lafranchi, another of the daughters of the All Nations' Lafranchis (Anon. 1901: 20). In addition to organizing community and sporting functions in Cardrona, Paterson led fundraising efforts during the First World War (Anon. 1916: 4). He worked a gold claim until 1926, and then mined part-time after his purchase of the hotel (McNeish 1984: 14). In 1936, after ten years happily managing the Cardrona, Etty Paterson died aged 61, and some of the legend that is now in the fabric of the Cardrona Hotel began to form as James ran the business on his own (Anon. 1936: 4). Twenty years later, he was found by the young writer, James McNeish.

McNeish's popular travelogue, Tavern in the Town (originally published in 1957), introduced Paterson's Cardrona Hotel to readers throughout New Zealand. This bestseller underwent four reprints and then, in 1984, was republished in an expanded, illustrated edition that contributed to total sales of over 10,000 (McNeish 2016). As McNeish introduced readers to the lonely, eccentric, taciturn Jim Paterson and his ramshackle goldfields pub on the dusty, unpaved Cardrona road, Tavern in the Town tapped a rich vein of nostalgia for the innocence of the 'good old days' of New Zealand's past. By 1956, Paterson had run the hotel alone for twenty years, keeping the paintings by, and pictures of, his wife adorning the walls. His eccentricity touched a chord with readers, and stories of Paterson controlling the drinks that drivers could have (if you were headed for Wanaka, two glasses of beer; if to the Crown Range, one only; and if you were a woman, you must abstain) became legendary (McNeish 1984: 16-18). McNeish celebrated, created and underlined this nostalgia, emphasizing simplistic, idealistic values that were perceived as being largely lost in New Zealand - with the exception of Jim Paterson (Davis 1979: 31).

Some tales of Jim Paterson defy modern minds and values, but, it must be admitted, more now than in the 1950s when Tavern in the Town was written. One has Paterson taking vacations to see the mid-year races in Christchurch, closing the door with a note: 'Beer under counter - help yourself', while others detail his battles with the Licensing Commission. In 1951, acting under a governmental imperative to reduce the number of licensed premises by closing marginal operations, the Licensing Commission determined that Paterson was not providing what the legislation required. Nevertheless Paterson, supported by the entire Cardrona population, successfully fought to keep his hotel open, which McNeish concluded'recognized the principle that
1.

2.

3.

4.

5.

6.

7.

8.

9.

10.

11.

12.

13.

14.

15.

16.

17.

18.

19.

20.

21.

22.

23.

24.

25.

26.

27.

28.

29.

30.

31.

32.

33.

34.

35.

36.

37.

38.

39.

40.

41.

42.

43.

44.

45.

46.

47.

48.

49.

50.

51.

52. 
1. a hotel, though practically falling to bits, might sometimes be greater than 2. the sum of its parts - that it might be a necessary social centre' (McNeish 1984: 15). A second attempt at cancelling the license in 1958 was thwarted by the combined support of a Wanaka policeman, the local doctor and Paterson's lawyer, who submitted a judgement that precipitate action would kill the old hotelier.

Through these stories of the ageing Paterson, the Cardrona Hotel morphed from a heritage structure to a witness to (albeit quixotic) history (Smith 2006: 91). In the revised edition of Tavern in the Town (1984), McNeish records the 1961 death of James Paterson and his burial in the Cardrona cemetery. Cardrona local Jack Galvin purchased the hotel, leaving it empty and near derelict until Edmund and Rosemary Jones purchased it in 1975. The Joneses restored the hotel, keeping the original facade, but adding concrete foundations, and a recycled timber floor, and rebuilding the structure. After their tenure, the property changed hands several more times, each new owner restoring it a little until, in 2002, it underwent a major renovation, which extended the accommodation to 21 bedrooms and enlarged the dining room and bar (Bauchop 2011).

James McNeish took a relatively unloved, near-anonymous wooden ruin on a minor Central Otago road and, in writing the portrait of its lonely owner, laid the foundations of the Cardrona's cultural mythopoeia. In the 1980s, the 1990s and the first decade of the 2000s, the marketers of Speight's Beer turned the Cardrona Hotel from McNeish's pages into the icon of popular culture that persists today.

\section{SPEIGHT'S BEER AND THE CARDRONA HOTEL}

Not long after New Zealand's alcohol television advertising laws were changed, Roy Meares of Saatchi \& Saatchi was tasked with reviving the fading Speight's brand. To combat the attitude of 'Drink Speight's, lose yer mates!' that was then prevalent among New Zealand drinkers, Meares created the 'Southern Man' campaign of laconic rugged men working and living in the sparse Central Otago landscape, consuming Speights as their drink of choice (Chandler 2012: 2). When the agency sought a hotel for the campaign narrative, they chose the Cardrona's distinctive facade, initially as background imagery, then rebranded (albeit with the facade unmistakably that of the Cardrona) for billboard use as the fictional 'Bonnie's Pub'. This was the ideal Speight's outlet, complete with its beautiful owner Bonnie out front, and the tag-line 'She's a hard road finding the perfect woman, boy'. Speight's is now the largest beer brand in New Zealand, thanks largely to Meare's work (Mathers 2013), but the campaign, despite its success, has been criticized for its idealized masculinity, diminution of women, nostalgia for the frontier, its monocultural casting and even for its boosterism of Southern New Zealand (Law 1997: 22-28; Jackson et al. 2009: 181-201; Towns et al. 2012: 389-401).

In 2000, the 3 Bald Men Design Company were asked to create a dozen Speight's Alehouse restaurants throughout the country, with a brief to incorporate 'the essence of "The Southern Man" image and its admired culture and heritage' into the architecture to create 'authentic Speight's dining experiences' (Speight's n.d.; Hobbs et al. n.d.). In 2002, this project reached new heights in terms of the relationship between the Cardrona and Speight's beer. At this time, a corporate Auckland alehouse site owner was also the owner of the Cardrona Hotel. In response to a very specific design brief to bring the two 
together, the 3 Bald Men team produced the Cardrona Mount Eden Alehouse in Auckland, a full architectural twin to its Otago namesake (Hendry 2002).

In 2007, in response to former Dannevirke farmer Tim Ellingham's plea for Speight's to become available in England, a Publicis Mojo-designed advertising campaign called 'The Great Beer Delivery' featured another replica Cardrona Hotel Speight's Alehouse. This replica was built and transported on the deck of the MV Lida from Dunedin to London via New York to serve Speight's beer to their London customers (Morris 2008). With the catch phrase, 'If you can't take your mate to the pub, take the pub to your mate', the selection of the crew, the building of the alehouse and the voyage across the world became an Internet sensation and was featured on overseas news shows and in numerous marketing programmes and lectures (Williamson 2009). As a result, the Cardrona has become not merely $a$ New Zealand hotel, but the New Zealand hotel. In terms of popular culture, the Cardrona had become an icon.

\section{IMPROBABLE HERITAGE SURVIVOR}

Neither Cardrona nor any of the other settlements of gold-rush-era Central Otago had an earlier frontier life. There were no roadside hotels (or roads), no stores, no maps and no knowledge of the newly farmed regions and, apart from a few newly erected, scratch-built farmhouses, there were very few buildings anywhere in Central Otago. After gold was found, in each place it was located an ephemeral rush settlement developed nearby, in what Erik Eklund termed 'a frontier-like, anarchic period of development' (2012: 10). Instead of following the standard geographical imperatives that determine the location of urban centres, development simply emerged out of convenient proximity to the miners and their workings. These rush towns, at least in their earliest stages, were like their residents: cosmopolitan, mobile and ready to be removed to a new field at the first cry of 'rush ho!' (Bell 2002: 26). This made for a business environment where the fortunes of the business owner were completely tied to the fortunes of the miners that he or she served. The towns were built on optimism, on the gamble that gold would continue to be found and that capital, investment, infrastructure and a level of stability could one day replace the uncertainty that dogged the rush centres (Dingle 1984: 78-80). However, this also meant that when the gold faded or ran out, the towns faded too. Inevitably, this caused a redistribution of goldfields urban centres that Dilsaver termed 'nucleation' of settlements, whereby small rush towns that, for a time, had supported a significant local population, shrank in size or even disappeared, while the constituent businesses and residents retreated into fewer, larger, more geographically ideal places (Dilsaver 1985: 17). In Central Otago, this saw settlements near Cardrona such as Gorge Town, Kirtleburn, Gibbston, Morven Ferry and Gee's Flat, disappear, while the larger settlements of Queenstown and Arrowtown soaked up the extra population and businesses.

On the face of it, Cardrona, and its hotel, should have suffered the same fate. Isolated, its gold mostly gone, with few residents beyond a handful of struggling sheep farmers battling the dry, harsh climate, a rabbit plague and unforgiving terrain, the business was located on a road that was tough to drive in summer and near-impassable in winter. Only a succession of dedicated, indomitable, quixotic and near-penniless owners meant that the Cardrona Hotel survived.

The lack of financial resources of Cardrona Hotel owners was more important in the process of preserving the structure than might be immediately
1.

2.

3.

4.

5.

6.

7.

8.

9.

10.

11.

12.

13.

14.

15.

16.

17.

18.

19.

20.

21.

22.

23.

24.

25.

26.

27.

28.

29.

30.

31.

32.

33.

34.

35.

36.

37.

38.

39.

40.

41.

42.

43.

44.

45.

46.

47.

48.

49.

50.

51.

52. 
1. apparent. Owners with money to spend might have been tempted to renovate and change the hotel, especially its distinctive facade. Most Otago hotels from the rush era have had modernizing plaster, roughcast or brick facades added, so that the hotels built in the very first days of the Central Otago rush - and that could arguably be called more foundational to the gold-rush story of the region than the Cardrona - bear little resemblance to their original versions that were erected in 1862 and 1863. Queenstown's Queen's Arms Hotel, for example, set up by famed goldfields policeman Sergeant Hugh Bracken in 1863 and taken over to become Eichardt's Hotel in 1868, could argue for equal status with the Cardrona as a heritage structure and business, but it lacks the 'colour' of a narrative associated with the benign neglect of the Cardrona Hotel's Jim Paterson - and it did not have a television beer campaign to popularize it.

Similarly, the New Orleans Hotel was one of the first hotels in the colourful, rambunctious frontier town that was known popularly as Fox's in 1863. Erected just after the now infamous lawless era when W. H. 'Bully' Hayes ran his United States Hotel and battled his rivals, the Buckingham family; largerthan-life characters such as 'The Redoubtable'William Fox ran the Golden Age Hotel; and goldfields songsters Charles 'The Inimitable' Thatcher and Madam Vitelli trod the stages of them all. The well-preserved establishment of the New Orleans Hotel, still operating in the heart of the tourist 'boom' town of Arrowtown, is rarely commented on for anything beyond its excellent fare, comfortable accommodation and stunning location, despite its venerable heritage credentials. Each of these hotels bears enough resemblance to their rush-era versions to be recognizable as heritage structures, but lack what the heritage consumer tourists construct in the Cardrona Hotel (which, especially its distinctive false-front facade, missed out on all of the possible renovator improvements) as a form of historical integrity, even if aspects of this are pastiche. The rusty 'Gaelic whiskey' sign on the Cardrona's facade, for instance, faithfully reproduced in the Mount Eden Speight's Alehouse copy of the Cardrona, is a modern addition and is entirely absent in historical pictures of the hotel. A valid comparison might be made with the 1882 mud brick Vulcan Hotel (originally the 'Ballarat)' at St Bathans. While it could actually argue for a greater level of structural integrity with the original structure than the Cardrona, the Vulcan Hotel was built twenty years later, and it missed out on the television marketing creativity that created, and cemented, the Cardrona's unique heritage persona in public imagination.

\section{FALSE-FRONT ARCHITECTURE}

Ultimately, it is the 'false-front' aspect of the Cardrona Hotel that allows everyone to see the hotel as having heritage and gold-era integrity. The facade's structure actually hides the myriad of changes, expansions, rebuilds, changes of room use and other architectural changes that lie behind it. Its false front, even in its name, declares a lack of a commitment to architectural truth, but this allows the owners to make alterations as they see fit, to repurpose and restructure as much as they like, behind the architectural stage curtain of Baltic pine first built by George Butler Bond in 1867.

The Illustrated Dictionary of Historic Architecture defines false-front buildings as having 'a front wall which extends beyond the sidewalls of a building to create a more imposing façade [or] a front wall that extends above the roof of a building' (Harris 1983: 208). Popularly associated with American fron- 
tier 'rush' areas, historic centres and ghost-towns creating the idea of 'boomtown architecture', false-front architecture is much older than the 'rush' era of the nineteenth century. False-front facades are found on 2000-year-old Zapotec ruins at Mitla, Mexico (Joyce 1911: 154-63), on the duomos of Florence and Siena, on Bernard Poyet's 1806 Paris Chamber of Deputies (Joly cited in Zanten 1989: 16-22) and on Greek Revival antebellum architecture in Southern United States (Zelinsky 1954: 9-12).

It is in its guise of 'frontier' architecture that it has become iconic and it is in this form that the Cardrona Hotel is viewed as a quintessential gold-rush relic by visitors, both local and international. The consensus among architectural historians has the appearance of false-front architecture in so-called 'boom' towns stemming from merchants, hoteliers and business owners being reluctant to pour money into what could be a short-lived, ephemeral town. Nevertheless, to project an image of stability and success to their customers, for the first few years they provided a solid facade, even if little more than canvas tents or corrugated iron shells stood behind these. Early photographs of railway towns, western mining centres and urban rush towns across the American West and throughout the mining areas of Australasia show business owners standing hopefully in front of these structures, while the artifice inherent in the buildings bestows the pejorative 'false' to the name of the architectural style.

The Cardrona Hotel is a false-front structure that, in large part, derives its renown from the perception of its unmodified facade. Fortunately, the succession of owners has regarded the facade as something to be left largely untouched, despite many and extensive changes to the roofline behind it (at least one renovation temporarily produced a peaked roof), and walls that have changed from canvas to iron to stone. If comparisons with other goldfields era hotels are made, it is hard to escape the conclusion that the only part of the Cardrona Hotel that is authentic is its false front, presenting a mental conundrum: if authenticity is derived from something inherently false, is it really authentic at all?

\section{CONCLUSION}

The incongruity of the replica false-fronted 'Cardrona twin' alehouses in urban Auckland and on a boat to London becomes part of the mythopoeia constructing the real Cardrona Hotel as an iconic part of popular culture in contemporary New Zealand. Stories of eccentric-yet-generous owners underscore the myth creation, assuring all that the nostalgia for this aspect of Otago's past is not only justified, but also a good thing. Through the marketing of beer in the media, and the enduring narrative of the 'lost' New Zealand society represented in the old lonely men behind an old goldfields pub bar, the hotel that George and Rebecca Bond built leaves the gold rush behind to become that most ephemeral of defined objects in modern society: a popular culture icon.

The Cardrona Hotel, then, is itself today constructed via nostalgia and a vague sense of knowing the structure through its promotion. This is a familiarity that is twinned to the false front of the architecture; the popular culture construction is just as false front as the hotel, but is less obviously so, especially as time passes. This means that the contemporary tourist driving on the Crown Range Road to, or from, Arrowtown, and who pauses at the Cardrona Hotel to engage with the presented facade, feels that they too are seeing history and heritage as it really was - and then pull out their camera and,
1. 2. 3. 4. 5. 6. 7. 8. 9. 10. 11. 12. 13. 
1. in turn, continue to promulgate its image. Whatever changes each owner 2. has wrought, the Cardrona Hotel is now New Zealand's most photographed hotel (Bauchop 2011), and whether it is George and Rebecca Bond's place, Jim Paterson's hotel or the Speight's Beer pub, it has emerged as an iconic part of New Zealand history, society and culture, and as such, has become a popular New Zealand gold-rush architectural icon.

\section{REFERENCES}

Anon. (1859), 'New insolvents', The Argus, 28 July, p. 6.

10.

_ (1862a), 'New diggings near Mount Watkins', Otago Daily Times, 16 August, p. 5.

- (1862b), 'Conditions of reward', Otago Daily Times, 19 August, p. 5.

- (1862c), 'Arrival of Fox and party with 300 ounces of gold', Otago Witness, 30 November, p. 4.

_ (1862d), 'Mining summary', Otago Witness, 29 November, p. 5.

- (1862e), 'The Dunstan: Important fresh discoveries', Otago Daily Times, 9 December, p. 7.

_ (1863), 'Manual of the Otago gold fields', Otago Daily Times, 10 March, p. 6.

_ (1864), 'General', Lake Wakatip Mail, 28 September, p. 3.

- (1865a),'Editorial', Otago Daily Times, 30 December, p. 4.

_ (1865b), 'Advertisements', Lake Wakatip Mail, 25 October, p. 1.

- (1866a), 'Advertisements', Lake Wakatip Mail, 24 March, p. 3.

- (1866b), 'Correspondence: Arthur's point bridge', Lake Wakatip Mail,

17 January, p. 2.

- (1866c), 'Extended jurisdiction', Lake Wakatip Mail, 25 July, p. 2.

_ (1866d), 'R. M. Court, Queenstown', Lake Wakatip Mail, 28 July, p. 3.

_- (1867), 'General', Lake Wakatip Mail, 24 August, p. 2.

(1868a), 'Dunstan', Otago Daily Times, 30 April, p. 5.

_ (1868b),'Advertisements', Lake Wakatip Mail, 2 April, p. 3.

_ (1869a), 'Licensing meeting, Hawea District', Dunstan Times, 1 December, p. 2.

_ (1869b), 'Mr J. L. Gillies' tour', Otago Witness, 18 September, p. 17.

- (1871), 'Macetown', Lake Wakatip Mail, 19 April, p. 2.

_ (1872),'Editorial', Lake County Press, 5 April, p. 2.

_- (1875a),'Cardrona', Lake Wakatip Mail, 23 December, p. 3.

- (1875b), 'Cardrona', Cromwell Argus, 13 October, p. 6.

_ (1876a), 'Editorial', Dunstan Times, 18 February, p. 3.

- (1876b),'Inquest', Cromwell Argus, 8 February, p. 3.

- (1876c), 'Advertisements', Cromwell Argus, 5 January, p. 1.

- (1876d), 'Mysterious disappearance', Cromwell Argus, 8 February, p. 2.

- (1876e), 'Inquest', The Otago Daily Times, 16 February, p. 4.

- (1878a), 'Resident Magistrate's Court', Lake County Press, 31 October, p. 3.

- (1878b), 'The floods in Lake County', Otago Witness, 19 October, p. 16.

- (1880a), 'Advertisements', Cromwell Argus, 27 July, p. 4.

- (1880b), 'Editorial', The Arrow Observer and Lakes District Chronicle,

23 September, p. 2.

_ (1883a),'Cardrona', Lake County Press, 29 November, p. 8.

- (1883b), 'Cardrona', Lake County Press, 27 December, p. 12.

- (1884),'Cardrona', Cromwell Argus, 1 April, p. 2.

(1885a), 'Local \& general', Lake County Press, 28 May, p. 2. 
- (1885b), 'Advertisements', Lake Wakatip Mail, 22 May, p. 1.

- (1885c), 'The Mountaineer hotel', Lake Wakatip Mail, 8 August, p. 6.

- (1885d), 'Editorial', Lake County Press, 16 April, p. 2.

- (1888a),'Editorial', Lake Wakatip Mail, 14 September, p. 2.

- (1888b), 'Cardrona', Cromwell Argus, 2 October, p. 2.

- (1889a), 'Mining intelligence: Cardrona', Cromwell Argus, 21 May, p. 2.

- (1889b), 'Mining intelligence: Cardrona notes', Cromwell Argus, 9 July, p. 2.

- (1890a), 'Editorial', Lake Wakatip Mail, 4 July, p. 2.

- (1890b), 'A trip to the Wanaka District', Lake Wakatip Mail, 21 March, p. 5.

- (1892), 'Local and general', Dunstan Times, 17 June, p. 2.

(1894), 'Telegraphic', Lake County Press, 15 November, p. 2.

(1895), 'Lake County', Otago Witness, 22 August, p. 22.

(1896a), 'Cardrona Notes', Lake Wakatip Mail, 28 February, p. 5.

- (1896b), 'Local and general', Lake County Press, 2 April, p. 2.

- (1896c), 'Cardrona', Lake County Press, 27 February, p. 7.

(1900), 'The fifth contingent: Otago section', Otago Witness, 15 March, p. 28.

- (1901), 'Wedding bells', New Zealand Tablet, 7 November, p. 20.

- (1916), 'Local and general', Lake County Press, 3 August, p. 4.

- (1921), 'Obituary', Lake Wakatip Mail, 15 November, p. 5.

- (1922), 'Licensing committee', Lake Wakatip Mail, 6 June, p. 5.

(1926), 'Editorial', Lake Wakatip Mail, 2 February, p. 4.

(1929), 'Obituary: George Magnus Hassing, pioneer historian', Otautau

Standard and Wallace County Chronicle, 8 January, p. 4.

(1936), 'Obituary', Lake Wakatip Mail, 7 July, p. 4.

Barnicoat, J. W. (n.d.), 'Extract from journal, April-October 1844, relating to the survey of Otago' (typescript), Dunedin: Hocken Library, Archive reference HM 882.

Bauchop, H. (2011), 'Cardrona hotel false front, Heritage New Zealand Pouhere Taonga, entry 2239', http://www.heritage.org.nz/the-list/details/2239. Accessed 22 June 2018.

Bell, P. (2002), 'The fabric and structure of Australian mining settlements', in E. W. Herbert, A. B. Knapp and V. C. Pigott (eds), Social Approaches to an Industrial Past: The Archaeology and Anthropology of Mining, London: Routledge, pp. 27-38.

Bond, G. B. (1876), Testamentary Register 1876-1882, 25 May, Dunedin: Archives New Zealand, C720955DAGID2479010.

Bond, R. (1876), 'Mr G. B. Bond's death: To the editor of the Cromwell Argus', Cromwell Argus, 29 February, p. 3.

Broad, L. (1865), 'Lakes district: Official report', Otago Witness, 23 December, p. 11.

Carpenter, L. W. (2011), 'Reviled in the record: Thomas Logan, and the origins of the Cromwell Mining Company, Bendigo, Otago', Journal of Australasian Mining History, 9, pp. 36-53.

Chandler, P. (2012), 'Roy's a southern man', Mountain Scene, 31 May, p. 2.

Davis, F. (1979), Yearning for Yesterday: A Sociology of Nostalgia, New York: Free Press.

Dilsaver, L. M. (1985), 'After the gold rush', Geographical Review, 75:1, pp. 1-18.

Dingle, T. (1984), Settling, McMahons Point: Fairfax, Syme \& Weldon.

Duncan, A. H. (1888), The Wakatipians or Early Days in New Zealand, Arrowtown, NZ: Lakes District Centennial Museum Incorporated.

Eklund, E. (2012), Mining Towns: Making a Living, Making a Life, Sydney: University of New South Wales Press.

1.

3.

4.

5.

6.

7.

8.

9.

10.

11.

12.

13.

14.

15.

16.

17.

18.

19.

20.

21.

22.

23.

24.

25.

26.

27.

28.

29.

30.

31.

32.

33.

34.

35.

36.

37.

38.

39.

40.

41.

42.

43.

44.

45.

46.

47.

48.

49.

50.

51.

52. 
Grogan, M. J. (1862), 'Grogan's diggings, Wilkinson's river, Cardrona', The Otago Witness, 22 November, p. 3.

Halabi, K. and Williams, E. (2010), 'Great Aussie pubs', Australian Geographic, 24 June, http://www.australiangeographic.com.au/topics/history-culture/ 2010/06/great-aussie-pubs. Accessed 18 June 2018.

Hall-Jones, J. (2005), Goldfields of Otago: An Illustrated History, Invercargill: Craig Print.

Harris, C. M. (1983), Illustrated Dictionary of Historic Architecture, New York: Dover Architecture.

Hendry, S. (2002), 'Theme bar for pride of the south', New Zealand Herald, 7 June, http://www.nzherald.co.nz/business/news/article.cfm?c_id=3\&objectid= 2045564. Accessed 18 June 2018.

Hobbs, W., Winter, N. and Small, S. (n.d.),'3 Bald Men', http://www.3baldmen. co.nz/speightsalehouse.html. Accessed 18 June 2018.

Jackson, S., Gee, S. and Scherer, J. (2009), 'Producing and consuming masculinity: New Zealand's (Speight's) "Southern Man"', in L. Wenner and S. Jackson (eds), Sport, Beer and Gender: Promotional Culture and Contemporary Social Life, Zurich: Peter Lang, pp. 181-201.

Joyce, J. A. (1911), 'Some features of Mexican architecture', The Burlington Magazine for Connoisseurs, 19:99, pp. 154-60, 163.

Keddell, J. (1862a), 'Official report', Otago Witness, 22 November, p. 3.

— (1862b), 'Dunstan: Official report', Otago Daily Times, 26 November, p. 6.

Law, R. (1997), 'Masculinity, place and beer advertising in New Zealand: The southern man campaign', New Zealand Geographer, 53:2, pp. 22-28.

Mathers, J. (2013), 'Are we drinking less beer?', New Zealand Herald, 17 March, http://www.nzherald.co.nz/lifestyle/news/article.cfm?c_id=6\&objectid= 10871672. Accessed 18 June 2018.

McClymont, W. G. (1940), The Exploration of New Zealand, Wellington: Government Print.

McNeish, J. ([1957] 1984), Tavern in the Town, Wellington: Reed.

- (2016), email to the author, 10 February.

Middleton, A. (2006), 'Mount Cardrona Station archaeological assessment of study area', http://www.qldc.govt.nz/assets/OldImages/Files/District_ Plan_Changes/Plan_Change_18_downloads/Supporting_Documents/ Mount_Cardrona_Station_archaeological_assessment.pdf. Accessed 18 June 2018.

Mitchinson, J., Thomson, J., Hindle, C. and Baylis, R. (1864), 'Terrace claim, Cardrona', Arrow Town Wardens Court Registration Book of Extended Claims, Transfers, Protected Claims, 8 March, Dunedin: Archives New Zealand, AE PG D568 22784 box 75.

Morris, C. (2008), 'How Speight's crossed the world', Otago Daily Times, 27 October, https://www.odt.co.nz/business/how-speights-crossed-world. Accessed 18 June 2018.

Norman, R. (1890), 'Rural Rambles from Wanaka to Dunedin', Otago Witness, 10 July, p. 31.

O'Mahony, G. B. and Clark, I. D. (2012), 'From inns to hotels: The evolution of public houses in Colonial Victoria', International Journal of Contemporary Hospitality Management, 25:2, pp. 172-86.

Perapatetic (1883), 'Sketcher: A trip round Lake County', Lake County Press, 9 February, p. 10.

Pyke, V. (1862), 'The Wakatip, Dunstan, and Mount Benger goldfields', Otago Daily Times, 24 December, p. 6. 
Ritchie, N. A. and Hooker, R. (1997), 'An archaeologist's guide to mining 1. terminology', Australasian Historical Archaeology, 15, p. 4.

Smith, L. (2006), Uses of Heritage, Oxford: Routledge. 3.

Speight's Ale Houses (n.d.), 'Fing Speight's', http://www.speights.co.nz/Find- 4. Speights/Alehouses. Accessed 18 June 2018.

Stephenson, J., Bauchop, H. and Petchey, P. (2004), 'Bannockburn heritage landscape study', Science for Education, 244, http://www.doc.govt.nz/ Documents/science-and-technical/SfC244b.pdf. Accessed 18 June 2018.

Temple, P. (1985), New Zealand Explorers, Christchurch: Whitcoulls.

Towns, A. J. Parker, C. and Chase, P. (2012), 'Constructions of masculinity in alcohol advertising: Implications for the prevention of domestic violence', Addiction Research and Theory, 20:5, pp. 389-401.

Tuckett, F. (1844), ‘Entry Saturday \& Sunday May 4 \& 5th, 1844, The survey of Otago, the future site of Dunedin', in Frederick Tuckett's Diary, From March 28th to June 1st 1844, http://www.enzb.auckland.ac.nz/document/?wid=51 90\&page $=1$ \&action $=$ null. Accessed 18 June 2018.

Williamson, C. (2009), 'Expats pulling pints for Poms in Speight's first UK pub', The Dominion Post, 18 February, http://www.stuff.co.nz/business/ 197019/Expats-pulling-pints-for-Poms-in-Speights-first-UK-pub. Accessed 18 June 2018.

Zanten, D. Van (1989), 'Nineteenth-century French government design of the monuments of Paris', Art Journal, 48:1, pp. 16-22.

Zelinsky, W. (1954), 'The Greek revival house in Georgia', Journal of the Society of Architectural Historians, 13:2, pp. 9-12.

\section{SUGGESTED CITATION}

Carpenter, L. W. (2018), 'The Cardrona Hotel: Creating a New Zealand heritage icon', Australasian Journal of Popular Culture, 7:2, pp. 209-24, doi: 10.1386/ ajpc.7.2.209_1

\section{CONTRIBUTOR DETAILS}

Lloyd Carpenter is a senior lecturer in Maori Studies and New Zealand History at Lincoln University. He coordinated and edited Rushing for Gold (Otago University Press, 2016), a new look at the Trans-Tasman goldfields, and has contributed to collections examining subjects ranging from the New Zealand Land Wars of the 1860s, to the history of and goldfields image use in the Otago wine industry. His current research continues his examination of aspects of built heritage, in particular, the landscapes and structures of the Australasian goldfields.

Contact: Faculty of Environment, Society and Design, Lincoln University, PO Box 85084, Christchurch 7647, New Zealand.

E-mail: lloyd.Carpenter@lincoln.ac.nz

Lloyd William Carpenter has asserted his right under the Copyright, Designs and Patents Act, 1988, to be identified as the author of this work in the format that was submitted to Intellect Ltd.

6.

7.

8.

9.

10.

11.

12.

13.

14.

15.

16.

17.

18.

19.

20.

21.

22.

23.

24.

25.

26.

27.

28.

29.

30.

31.

32.

33.

34.

35.

36.

37.

38.

39.

40.

41.

42.

43.

44.

45.

46.

47.

48.

49.

50.

51.

52. 